\title{
Physicochemical characterization, carotenoid content and protein digestibility of pumpkin access flours for food application
}

\author{
Aline Machado PEREIRA ${ }^{1 *}$ (D), Fernanda Doring KRUMREICH ${ }^{1}$, Adriano Hirsch RAMOS ${ }^{1}$, \\ Ana Cristina Richter KROLOW ${ }^{2}$, Roberta Bascke SANTOS ${ }^{1}$, Marcia Arocha GULARTE ${ }^{1}$
}

\begin{abstract}
Pumpkin (Cucurbita maxima) research has been growing because of its characteristics, such as the attractive color, low-cost production, nutritional potential, and functional properties for food application. In this context, pumpkin processing for flour production provides a full possibility for the consumption of this vegetable, being thus an alternative for the agribusiness. Research institutes are developing new genotypes for multiple applications of this vegetable. The objective of this study was to characterize pumpkin flours from four access and evaluate its physicochemical characteristics, carotenoid content, and protein digestibility. The dried pumpkins were ground in a knife mill and stored in a glass bottle at room temperature and protected from light. The pumpkin flours presented different proximal composition. All flours presented low water activity, which is microbiologically safe for storage. As for the absorption index and water solubility, both presented high values compared to the values of other flours found in the literature. The flours presented colorimetric profile from yellow to orange, and are rich sources of carotenoids and fibers. The four samples presented high values of protein digestibility, desired for food application. The results indicate that the four pumpkin access flours are indicated for application in foods.
\end{abstract}

Keywords: Cucurbita maxima; proximal composition; intense color.

Practical Application: Pumpkin accessions have desirable characteristics st for application in the food industry.

\section{Introduction}

Fruits and vegetable consumption are essential for feeding and has been expanding lately due to a health concern, intensifying the demand for foods that present practicality and high-quality nutritional and sensory value. Pumpkin (Cucurbita maxima) belongs to the Cucurbitaceae family, and it is widely grown all over the world. The fruit has significant participation in the diet of many countries. In addition to being used as a horticultural product, pumpkin also has medicinal use, having antihypertensive, bactericide, antidiabetics, anti-inflammatory, and antioxidant properties (Adams et al., 2011).

Several studies reported the characterization of the physicochemical and bioactive compounds of plants from the Cucurbitaceae family. These vegetables are source of phenolic compounds, carotenoids, vitamins (vitamin A, thiamine, riboflavin, vitamin $\mathrm{B}_{6}$, Vitamin $\mathrm{C}$, vitamin $\mathrm{E}$, and vitamin $\mathrm{K}$ ) amino acids, carbohydrates and minerals (potassium, phosphorus, magnesium, iron, and selenium) (Zhang et al., 2000; Wang et al., 2002). Pumpkin belongs to a group of healthy and functional foods, rich in phenolic compounds (flavonoids and phenolic acids), carotenoids, and vitamins, and the nutritional value of pumpkin fruits is high but varies between varieties (Tamer, 2010; Guz et al., 2018). Carotenoids, especially $\beta$-carotene, has been identified as the pigment responsible for the yellowish color in pumpkin. Carotenoids confer protection against cellular damage by free radicals, thus reducing the risk of cancer. $\beta$-carotene is also an essential source of vitamin A (Lee et al., 2002). The attractive color imparted by pumpkin could improve the appearance of food. According to Lee et al. (2002), the colorimetric profile indicates the potential of pumpkin to be processed into flour and added into a food product. Mehditabar et al. (2019) studied the influence of pumpkin puree and guar gum on bioactive, rheological, thermal and sensory properties of ice cream, and found that the enrichment of ice cream with pumpkin puree presented higher phenolic content, fiber content and free radical elimination activity (DPPH) of ice cream, proposing significant effects on the color and flavor of ice cream, and can be a useful substitute. Yildiz \& Ozcan (2019) studied the functional and textural properties of plant fibers in enriched yogurt and the highest antioxidant capacity was detected in pumpkin-enriched yogurt, which corresponded to the higher levels of total phenolics, ascorbic acid and total carotenoids. These studies demonstrate the potential of pumpkin-derived products for food application and the improvement in the nutritional properties that these products can provide.

Pumpkins are vegetables that have excellent expansion potential in the market, but its dimensions, storage, and handling can cause many losses. Drying is an alternative to fresh fruit used in the food industry, as it allows its use during the off-season. Drying is a method used for food conservation, and its goal is to remove water from food to a content where deterioration reactions are minimized. Also, it provides longer shelf time, originates less need for storage space and is lighter for transportation, 
thus becoming an excellent option to produce pumpkin flour (Guiné et al., 2011; Alibas, 2007). One of the challenges of plant breeding is to combine nutritional quality with good industrial yield and decrease post-harvest losses.

The industry's most significant challenge to meet consumer desires is to produce foods that exhibit nutritional characteristics close to natural, sensitive, and enjoyable products that exhibit stability during storage (Silva et al., 2011). Studies with pumpkin have grown due to some characteristics such as their attractive color, their low cost of production, and their nutritional potential. Well executed pumpkin processing generates nutrient-rich products, e.g., pumpkin meal.

Pumpkin meal production provides an alternative for the consumer, thus being able to be an alternative to the agribusiness. Most of the current studies emphasize the use of pumpkin seed residues, and until the end of this study, there was no study with the flour obtained through the whole fruit. Studies on the functional properties of pumpkin seeds can stimulate their consumption, using it in cooking preparations and the elaboration of new foods, besides representing an alternative for full use of the pumpkin. The pumpkin flour is easy to use as a supplement of $\beta$-carotene in food products. It can be used producing a variety of prepared food products in bakery mixes by adding color, flavor, and moisture to mixtures (Yok et al., 2016).
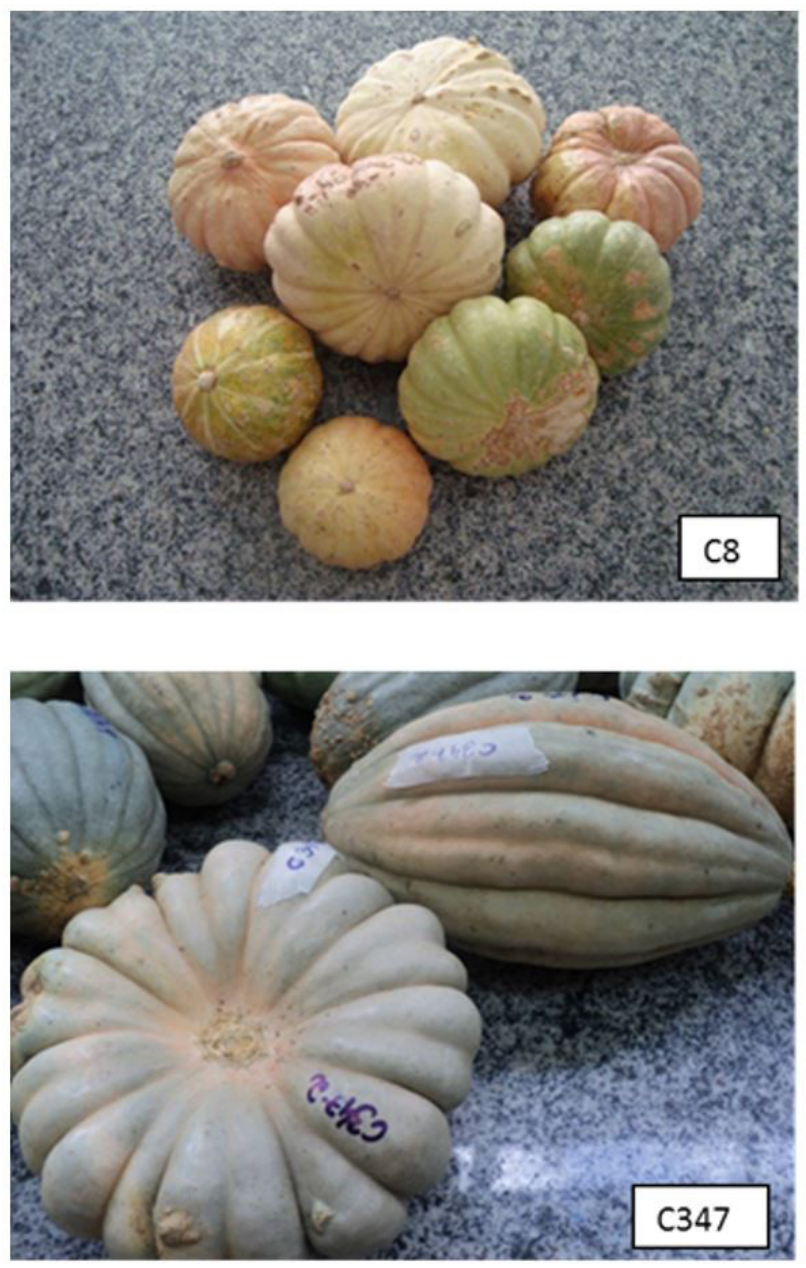

Pongjanta et al. (2006) demonstrated the potential of pumpkin flour in confectionery products. They reported that wheat flour could be replaced by $20 \%$ pumpkin powder for butter cake and chiffon cake, while $10 \%$ replacement for sandwich bread, sweet bread, and cookies. Batista et al. (2018) partially replaced wheat flour $(0 \%, 25 \%, 50 \%$, and $75 \%)$ by pumpkin seed flour in the production of cupcakes stuffed with carob and proved to be a viable alternative for the use of this co-product, contributing to an increase in proteins and providing greater texture, cohesion, $\mathrm{pH}$, soluble solids, and the formulation with 50\% pumpkin flour was considered best due to similarities with the formulation of $100 \%$ wheat flour.

In this context, the objective of this study was to evaluate the physicochemical, bioactive compounds, and protein digestibility of flours from four accessions of pumpkin.

\section{Materials and methods}

\subsection{Material}

The Pumpkin Active Germplasm Bank provided pumpkins used in this study from Embrapa Clima Temperado - Pelotas/RS, Brazil. The evaluated accesses of Cucurbita maxima creole varieties were C8, C347, C269, and C389 (Figure 1) and labeled as F1, F2, F3, and F4, respectively.
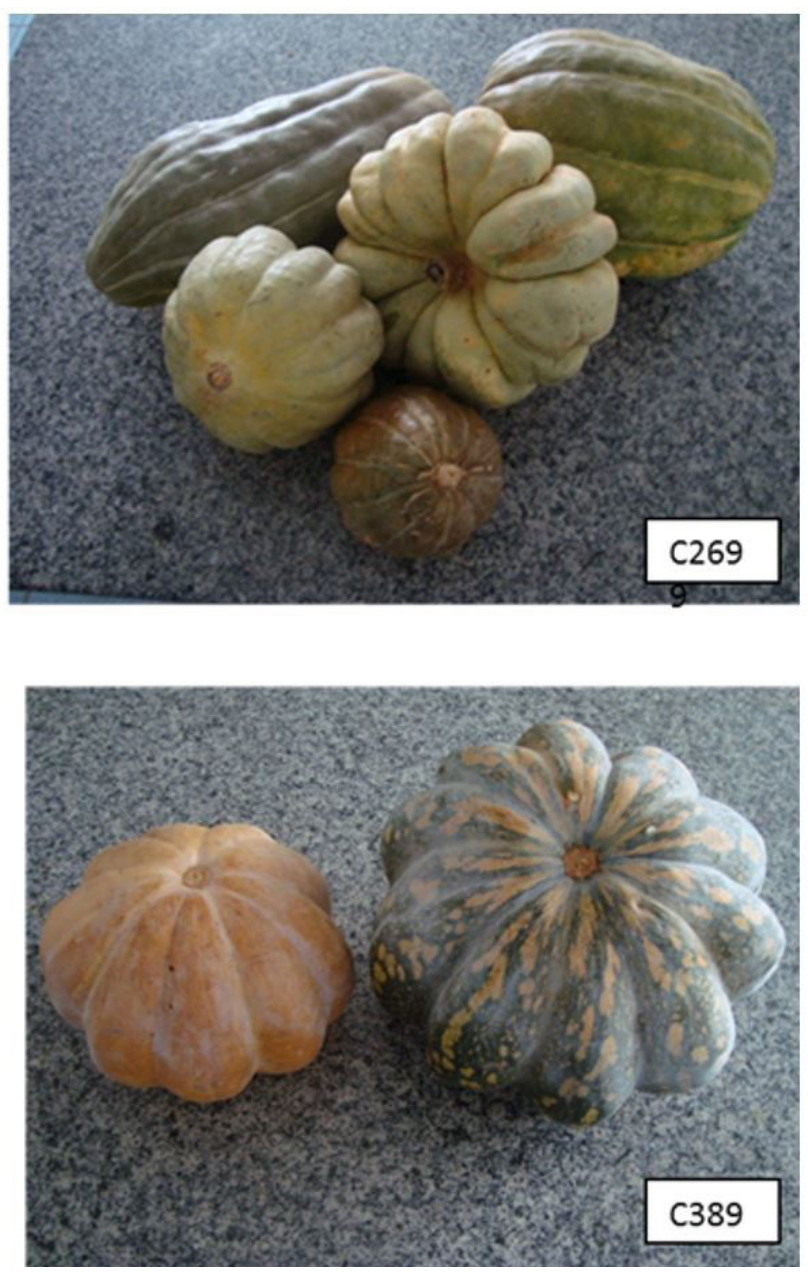

Figure 1. Accesses of Cucurbita maxima creole varieties, F1 = C8; F2 = C347; F3 = C269; F4 = C389. 


\subsection{Sample preparation}

Sample preparation occurred in the dependencies of Embrapa Clima Temperado's analytic center. The sample was prepared using 20 fruits of approximately $200 \mathrm{~g}$ each. First, the pumpkins went through a washing process using deionized water to remove the superficial dirt. Afterward, the fruits were cut, and the seeds and peels were discarded, and then sliced lengthwise. Then, samples were dried at $65^{\circ} \mathrm{C}$ in a laboratory oven, with air circulation to a moisture content of $6 \%$. The pumpkin pulps (Figure 2 ) were then processed into flour and ground in a knife mill (Perten, Model Laboratory Mill 3100) and stored at room temperature and protected from light until the analyses were carried out.

\subsection{Proximal composition, energy value and amylose content}

The moisture content was determined according to the 352.2 methods of the American Society of Agricultural Engineers (2000) at $105^{\circ} \mathrm{C}$ for 24 hours. For ash content analysis, the sample was charred and placed in muffle at $500-600{ }^{\circ} \mathrm{C}$ until constant weight. For crude protein was made by the micro Kjeldahl method. The lipid content analysis was performed in a Soxhlet apparatus for 6 hours, using petroleum ether as solvent (Association of Official Analytical Chemists, 2005). The fiber analysis was carried out by the enzyme method of the American Association Cereal Chemists (1991). The percentage of carbohydrates in the samples was obtained by the difference between 100 and the sum of the contents of proteins, fats, fibers, moisture content, and ash. For the determination of the energy value, the Atwater conversion factors of $4.0 \mathrm{kcal} \mathrm{g}^{-1}$ were used for protein and carbohydrate and $9.0 \mathrm{kcal}^{-1} \mathrm{~g}^{-1}$ for fat (Brasil, 2003). The results were expressed on a dry basis.

The amylose content was determined by the colorimetric method with iodine, proposed by McGrance et al. (1998), with slight modifications by Hoover \& Ratnayake (2001). Approximately $20 \mathrm{mg}$ of the defatted sample with $8 \mathrm{~mL}$ of DMSO solution $90 \%$ (dimethylsulfoxide) were placed in the bath at $90{ }^{\circ} \mathrm{C}$ for 2 hours, stirred every 30 minutes. After cooling, the contents were transferred to a $25 \mathrm{~mL}$ volumetric flask and homogenized. An aliquot of $1 \mathrm{~mL}$ of the solution was added from $5 \mathrm{~mL}$ of $\mathrm{I}_{2}$ solution/KI $\left(0.0025 \mathrm{~mol}\right.$. $\mathrm{L}^{-1}$ of $\mathrm{I}_{2}$ e $0.0065 \mathrm{~mol}$. $\mathrm{L}^{-1}$ of $\left.\mathrm{KI}\right)$, and the volume completed to $50 \mathrm{~mL}$. The resulting solution was homogenized and kept at rest for 15 minutes before reading the absorbance at $600 \mathrm{~nm}$. For the completion of the calibration curve, $20 \mathrm{mg}$ of pure potato amylose (of the Sigma mark) was used for the same procedure described for the samples and aliquots of 0.1 are withdrawn; $0.2 ; 0.4 ; 0.6 ; 0.8$ and $1.0 \mathrm{~mL}$ for absorbance determination.

\subsection{Water activity (Aw)}

The water activity (Aw) was performed in a water activity equipment (Novasina, model LabTouch-Aw).

\subsection{Water absorption index and water solubility index}

The water absorption index (WAI) was determined, according to Anderson et al. (1969), with adaptations. In a centrifugal tube, approximately $2.5 \mathrm{~g}$ of a sieved sample was placed, and $30 \mathrm{~mL}$ of distilled water at $28^{\circ} \mathrm{C}$. The tubes remained in mechanical agitation in a water bath at $28{ }^{\circ} \mathrm{C}$ for 30 minutes and then centrifuged at $3000 \mathrm{rpm}$ for 10 minutes. Then, $10 \mathrm{~mL}$ of the supernatant was carefully pipetted into aluminum capsules and taken to a heater at $105{ }^{\circ} \mathrm{C}$ for 4 hours. After this period, the material was cooled in a desiccator and weighed in analytical scales, the value obtained from the evaporation residue. The remaining liquid in the centrifuge tube has been carefully disposed of, the remaining gel (centrifugal residue) heavy and the WAI calculated according to Equation 1:

$W A I=C R W / S W-E R W$

where: WAI = Water absorption index (gel weight $(\mathrm{g}) /$ dry matter (g)); CRW = Centrifuge residue weight (g); SW = Sample weight (g) (dry base); ERW = Evaporation residue weight (g).

The Water Solubility Index (WSI) was determined according to Anderson et al. (1969) and calculated by the relationship between the weight of the evaporation residue and the dry weight of the sample, according to Equation 2:

$W S I=(E R W / S W) * 100$

where: WSI = Water Solubility Index (\%); ERW = Evaporation residue weight (g); SW = Sample Weight (g) (dry base).

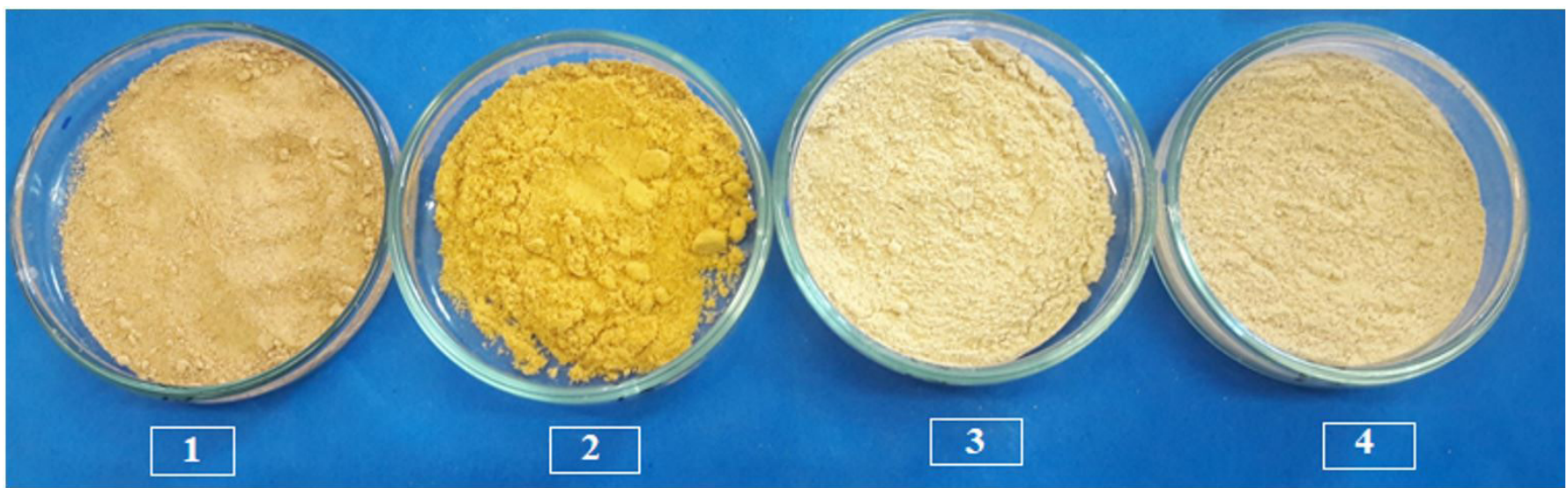

Figure 2. Pumpkin flours, $1=$ F1; $2=$ F2; $3=$ F3; 4 = F4. 


\subsection{Colorimetric profile}

The colorimetric profile of the pumpkin flour was determined using a colorimeter (Minolta, CR-310, Osaka, Japan).

\subsection{Carotenoid content}

The determination of the carotenoids was performed according to the method described by Rodriguez-Amaya (2001). The extraction was made with cold acetone for 10 minutes with the help of a magnetic shaker. The material was filtered, and the residue was washed with the same solvent until it was colorless. The filtrate was transferred to a separating funnel, in which it was added $30 \mathrm{~mL}$ of petroleum ether and $100 \mathrm{~mL}$ of distilled water. After the separation of the phases, the phase containing petroleum ether was transferred to a volumetric flask. It was used a spectrophotometer (JENWAY 6705 UV/Vis.) with a wavelength of $450 \mathrm{~nm}$. The contents of total carotenoids were determined by the molar absorption coefficient of the carotenoids in the solvent of petroleum ether through the equation: $\mathrm{ABS} / 2500$, where $\mathrm{ABS}$ is the absorbance and 2.500 is the molar extinction coefficient of $\beta$-carotene. The results were expressed in $\mu \mathrm{g}$ of $\beta$-carotene.

\subsection{Protein digestibility}

Protein digestibility was performed following the methodology described by Hsu et al. (1977), with adaptations. An enzymatic solution containing the enzymes trypsin and pancreatin was used for the hydrolysis of the protein solution. The $\mathrm{pH}$ of $50 \mathrm{~mL}$ of the protein suspension in distilled water (containing $6.25 \mathrm{mg}$ protein $/ \mathrm{mL}$ ) was adjusted to $\mathrm{pH} 8.0$ with stirring in a water bath at $37^{\circ} \mathrm{C}$. Five milliliters of the enzyme solution was added to the protein suspension maintained in a water bath at $37^{\circ} \mathrm{C}$. The $\mathrm{pH}$ drop was measured after the addition of the enzyme solution, from 15 seconds and then every minute over 10 minutes, using a potentiometer. The $\mathrm{pH}$ drop was observed over 10 minutes, and the Equation 3 of the parameters was used to describe the correlation with true digestibility in vivo.

Protein digestibility $(\%)=210.46-18.103 \mathrm{X}$

where: $\mathrm{X}$ represents the $\mathrm{pH}$ determination.

\subsection{Statistical analysis}

Analytical determinations for the samples were performed in triplicate, and standard deviations were reported. A comparison of the means was ascertained by a Tukey's test to a 5\% level of significance using an analysis of the variance (ANOVA).

\section{Results and discussion}

\subsection{Proximal composition, energy value, and amylose content}

The proximal composition, energy value, and amylose content of pumpkin flours are presented in Table 1.

The initial moisture content varied from $84.6 \%$ to $95.5 \%$, and the lowest value was for F2 and the highest for F4, respectively, presenting unfavorable to the conservation of this product, due to its rapid decomposition. Similar results were found by Moreira et al. (2020), who reported the effect of different cooking techniques on carotenoids and antioxidant activity of biofortified pumpkins, found in raw samples moisture content between 80.8 and $90.5 \%$. With drying, moisture content decreases 11 times (average), making the product more stable and maintaining the quality and conservation of this fruit. Park et al. (2001) reported the advantages of the drying in the pumpkin process, among them the ease in product conservation, the stability of aromatic components at room temperature, protection against enzyme and oxidative degradation.

Crude protein values were verified between 7.7 and 9.5\% for F3 and F1 accesses, respectively. No difference was found for crude protein contents between accessions $(P>0.05)$. See et al. (2007) analyzed the proximal composition of pumpkin flour produced from the seeds (Cucurbita moschata) and found a protein content of $9.6 \%$. Lipid content ranged from 1.4 to $5.9 \%$ for F3 and F2 accessions, respectively. F3 and F4 did not differ significantly.

The ash content varied from 5.8 to $9.4 \%$ for F2 and F3 access, respectively. Statistical difference was verified between the flours, except for the F1 and F2 flours. The higher lipid content was verified in the F3 and F4 accessions, and these results may be related to the higher lipid values found in these accessions, decreasing the ash fraction. Minerals perform vital functions in the body, the intake of these favors the balance and maintenance of essential bodily functions, the F3 flour stands out from the others in the mineral content and becomes a suitable alternative for ingesting these. Saeleaw \& Schleining (2011) analyzed the composition, physicochemical and morphological characterization of pumpkin flour and found ash content of 5.4\%, lower values compared to this study.

As for the fiber content, pumpkins flours presented values between 11.6 to $19.2 \%$ for F2 and F1, respectively. There was a

Table 1. Proximal composition, energy value and amylose content of pumpkin flours.

\begin{tabular}{|c|c|c|c|c|}
\hline Flours & F1 & F2 & F3 & F4 \\
\hline Pulp initial moisture (\%) & $91.3 \pm 0.3^{c}$ & $84.6 \pm 0.3^{\mathrm{d}}$ & $95.1 \pm 0.6^{\mathrm{b}}$ & $95.5 \pm 0.3^{\mathrm{a}}$ \\
\hline Flour Moisture (\%) & $10.7 \pm 0.5^{\mathrm{a}}$ & $6.8 \pm 0.3^{\mathrm{c}}$ & $7.3 \pm 0.6^{c}$ & $9.0 \pm 0.5^{\mathrm{b}}$ \\
\hline Protein (\%) & $9.5 \pm 1.1^{\mathrm{a}}$ & $8.2 \pm 0.7^{\mathrm{a}}$ & $7.7 \pm 0.3^{\mathrm{a}}$ & $7.7 \pm 0.6^{\mathrm{a}}$ \\
\hline Lipids (\%) & $1.7 \pm 0.1^{\mathrm{b}}$ & $5.9 \pm 0.1^{\mathrm{a}}$ & $1.4 \pm 0.0^{c}$ & $1.5 \pm 0.0^{c}$ \\
\hline Ash (\%) & $6.4 \pm 0.1^{\mathrm{c}}$ & $5.8 \pm 0.4^{c}$ & $9.4 \pm 0.3^{\mathrm{a}}$ & $7.7 \pm 0.1^{\mathrm{b}}$ \\
\hline Fibers (\%) & $17.5 \pm 1.2^{\mathrm{ab}}$ & $11.6 \pm 1.6^{c}$ & $19.2 \pm 1.5^{\mathrm{a}}$ & $13.6 \pm 1.8^{\mathrm{bc}}$ \\
\hline Carbohydrates (\%) & $54.2 \pm 2.2^{\mathrm{b}}$ & $61.8 \pm 2.3^{\mathrm{a}}$ & $54.9 \pm 2.2^{\mathrm{b}}$ & $60.4 \pm 0.9^{\mathrm{a}}$ \\
\hline Energy value (kcal) & $270.4 \pm 65^{b c}$ & $333.3 \pm 7.1^{\mathrm{a}}$ & $263.5 \pm 7.9^{c}$ & $286.1 \pm 5.5^{\mathrm{b}}$ \\
\hline Amylose content (\%) & $1.4 \pm 0.9^{\mathrm{ab}}$ & $3.0 \pm 0.5^{\mathrm{a}}$ & $2.0 \pm 0.9^{\mathrm{ab}}$ & $0.9 \pm 0.3^{\mathrm{b}}$ \\
\hline
\end{tabular}

Simple arithmetic averages $(n=3) \pm$ standard deviation, followed by different lowercase letters on the same line, differ from each other by the Tukey test $(P<0.05)$; Results expressed on a dry basis. 
significant difference between all accesses. According to Brasil (1998), foods containing 6\% or more are considered foods with high fiber content. In this way, the flours can be considered fiber-rich food.

Total carbohydrate content varied from 54.2 to $61.8 \%$ for F1 and F3 flours, respectively.

F2 and F4 presented the highest carbohydrate values when compared to accessions F1 and F3, however, the carbohydrate values are lower when compared to the results found by Saeleaw \& Schleining (2011) for pumpkin flour, which reported 79.57\% of total carbohydrate. The energy value differed between the samples, and the lowest value found was for flour F3 and the highest value for F4 flour from 263.5 to $333.3 \mathrm{kcal}$, respectively.

Pumpkin flours showed amylose content between 0.9 and 3.0\% for F4 and F2, respectively, and these flours showed a significant difference. The flours can be classified as waxy for F1, F3, and F4 (which have a shallow content of amylose) and minimal amylose content for $\mathrm{F} 2$ flour. The proportions in which the amylose chains appear to differ between varieties, it can be classified as waxy (1-2\% of amylose), very low amylose content (above 2 to $12 \%$ ), low (above 12 to 20\%), intermediate (above 20 to $25 \%$ ) and high (from 25 to 33\%), according to Juliano (1993). With these results, it can be observed that the pumpkin flours present low apparent amylose content, which presents as a differential to provide energy quickly to the body and, consequently, faster digestion. The starch is made up of two polysaccharides, amylose, and amylopectin. As higher the proportion of amylopectin in higher food will be its glycemic index (digestion occurs faster). The amylopectin, which is made up of branches, is more readily hydrolyzed in the small intestine than amylose, which is a single linear filament. The ramifications increase the surface area that will suffer the action of hydrolytic enzymes, thus causing a more significant glycemic response, whereas, in starch-rich foods in the form of amylose, the glycemic response will be lower (Pi-Sunyer, 2002).

Variations found for moisture content, crude protein, lipid, ash, carbohydrate, energy value, and amylose content occur due to genetic variability between accessions. The genotypes used in this study are genetically distinct, with different characteristics, Ferreira et al. (2016) mentions that this genetic variability of pumpkins is of great importance for genetic improvement favoring the selection of parents with adequate vegetative, reproductive and disease resistance development; thus the results found are essential for breeders to follow in the process of selection and launch of new cultivars in the market.

\subsection{Water activity, water absorption index and water solubility index}

The water activity, water absorption, and solubility index from pumpkin flours are presented in Table 2.
The water activity varied from 0.21 to 0.33 for $\mathrm{F} 3$ and $\mathrm{F} 4$, and F1, respectively. Pumpkin flours showed a significant difference in water activity values, except for F3 e F4, being microbiologically safe. Noor Aziah \& Komathi (2009) study studying the color, proximate composition, water and oil holding capacities, and water activity hat the peeled pumpkin pulp flour (PPPF) and unpeeled pumpkin pulp flour (UPPF), reported presented water activity of 0.24 and 0.21 respectively. Products with a water activity below 0.6 provide adequate control for storage (Krist et al., 1999). The water activity parameter is essential in the food industry, influencing the deterioration by micro-organisms, enzymatic, and chemical reactions occurring during storage (Fellows, 2006). In general, the food industry controls this parameter to define shelf life and to ensure features like the texture of the products.

The WAI of the pumpkin flours varied from 6.2 to 11.5 (g dry matter gel/g), respectively, for F2 and F3, with no significant difference between F3 and F4 $(P>0.05)$. The water absorption index (WAI) is a relevant property for applications in products such as bread and cakes because high values help to maintain the moisture content of these products (Riaz, 2006).

The WSI varied from 17.3 and $18.2 \%$ for $\mathrm{F} 1$ and $\mathrm{F} 2$, respectively. The accessions did not differ statistically. The solubility depends not only on starch but also on interaction with other nutrients such as proteins and their structural modifications after gelatin. The values of WSI and WAI found for the pumpkin flours are high compared to the values of various flours found in the literature. Tavares et al. (2012) analyzed functional changes of toasted rice flour with microwave, varying moisture content, and processing time and found lower results, being the WAI of 2.8 ( $\mathrm{g}$ dry matter gel/g) and the WSI of $1.2 \%$. For the F3 and F4 flours, it was not possible to calculate the WSI, since they fully absorbed the water after centrifugation. These flours, therefore, can be used as a thickener in liquid and semi-liquids foods since the flours were able to absorb water and swell for improved consistency in food (Saeleaw \& Schleining, 2011). Que et al. (2008) analyzed the solubility and absorption of pumpkin flours produced by hot air-drying and freeze-drying and found values of 30.7 and $2.7 \%$, respectively. The results were higher and lower, respectively, for WSI and WAI when compared to our study.

The WAI and WSI are essential in evaluating the suitability of the use of flours; these values can be used to estimate the convenience of products, the higher the solubility, the better indication of the potential for use in food systems. WSI is an essential parameter in the characterization of flours for posterior solubilizing, as is the case of soups for example, because, through this, it can be verified the degree of baking of the starch and evaluate the conditions of solubilizing in aqueous ambient (Ascheri, 2009; Silva et al., 2011; Augusto-Ruiz et al., 2003).

Table 2. Water activity, water absorption index (WAI) and water solubility index (WSI) of pumpkin flours.

\begin{tabular}{|c|c|c|c|c|}
\hline Flours & $\mathrm{F} 1$ & F2 & F3 & F4 \\
\hline Water activity & $0.33 \pm 0.0^{\mathrm{a}}$ & $0.26 \pm 0.0^{\mathrm{b}}$ & $0.21 \pm 0.0^{\mathrm{c}}$ & $0.21 \pm 0.0^{c}$ \\
\hline WAI (g gel/g de matéria seca) & $8.4 \pm 2.5^{\mathrm{b}}$ & $6.2 \pm 0.5^{c}$ & $11.5 \pm 0.1^{\mathrm{a}}$ & $11.2 \pm 0.1^{\mathrm{a}}$ \\
\hline WSI (\%) & $17.3 \pm 2.5^{\mathrm{a}}$ & $18.2 \pm 0.5^{\mathrm{a}}$ & - & - \\
\hline
\end{tabular}

Simple arithmetic averages $(\mathrm{n}=3) \pm$ standard deviation, followed by different lowercase letters on the same line, differ from each other by the Tukey test $(P<0.05)$. 


\subsection{Colorimetric profile} Table 3 .

The colorimetric profile of pumpkin flours is presented in

The value of $\mathrm{L}^{*}$ varied from 73.7 to 84.1 for F1 and F3 accessions, respectively. F3 presented the higher value of $\mathrm{L}^{*}$, followed by F4, F2, and F1, respectively $(P<0.05)$. Noor Aziah \& Komathi (2009) obtained similar results, reporting that the peeled pumpkin pulp flour and unpeeled pumpkin pulp flour utilized in their studies had an $\mathrm{L}^{*}$ value of 63.4 and 64.9, respectively.

The flours presented values of $\mathrm{a}^{*}$ between 0.8 and 4.7 and values of $\mathrm{b}^{\star}$ between 28.1 and 46.7 for F4 and F2 flours, respectively. Positive values of $\mathrm{a}^{*}$ indicate a reddish color, while positive values of coordinate $b^{*}$ indicate the yellow color. Pumpkin flours presented yellow-orange color, and F2 flour presented the higher $\mathrm{b}^{*}$ values $(P<0.05)$, presenting an intense orange color. Therefore, the presence of more carotenoids in the F2 could be the most probable reason for the higher degree. Pigments are concentrated after drying, and the color of the product becomes intensive. The flour color is an essential factor for its marketing and use as an ingredient in various product formulations. The yellow-orange color of pumpkins can be explained by the natural presence of carotenoids (Noor Aziah \& Komathi, 2009).

\subsection{Total carotenoid content and protein digestibility}

The total carotenoid content and protein digestibility of pumpkin flours is presented in Table 4 .

The flours presented carotenoid contents between 38.7 and 180.6 mg.g ${ }^{-1}$ for F1 and F2, respectively. F2 flour, therefore, has five times higher carotenoid content than F1 flour, twice as much as F3 and three times than F4 $(P<0.05)$. These results are corroborated, due to the more intense yellow-orange color, because carotenoids are responsible for the yellow and red color of fruits and are used commercially as a food dye and in nutritional supplements (Maldonado-Robledo et al., 2003; Fraser \& Bramley, 2004). Also, F2 access was the one that presented the highest lipid content, and the high content of total carotenoids was also verified, presenting a more intense yellow-orange

Table 3. Pumpkin flour colorimetric profile.

\begin{tabular}{crrrr}
\hline Flours & \multicolumn{1}{c}{ F1 } & \multicolumn{1}{c}{ F2 } & \multicolumn{1}{c}{ F3 } & \multicolumn{1}{c}{ F4 } \\
\hline $\mathrm{L}^{*}$ & $73.7 \pm 0.6^{\mathrm{d}}$ & $75.1 \pm 0.5^{\mathrm{c}}$ & $84.1 \pm 0.3^{\mathrm{a}}$ & $80.3 \pm 0.4^{\mathrm{b}}$ \\
$\mathrm{a}^{*}$ & $4.7 \pm 0.1^{\mathrm{a}}$ & $3.6 \pm 0.1^{\mathrm{b}}$ & $-0.8 \pm 0.1^{\mathrm{d}}$ & $0.7 \pm 0.1^{\mathrm{c}}$ \\
$\mathrm{b}^{*}$ & $34.2 \pm 0.6^{\mathrm{b}}$ & $46.7 \pm 0.6^{\mathrm{a}}$ & $28.9 \pm 0.4^{\mathrm{c}}$ & $28.1 \pm 0.3^{\mathrm{d}}$ \\
\hline
\end{tabular}

Simple arithmetic averages $(\mathrm{n}=10) \pm$ standard deviation, followed by different lowercase letters on the same line, differ from each other by the Tukey test $(P<0.05)$.

Table 4. Total carotenoid content and protein digestibility of pumpkin flour.

\begin{tabular}{ccc}
\hline Flours & $\begin{array}{c}\text { Carotenoids } \\
\left(\mu \mathrm{g} \cdot \mathrm{g}^{-1}\right)\end{array}$ & $\begin{array}{c}\text { Protein Digestibility } \\
(\%)\end{array}$ \\
\hline F1 & $38.7 \pm 0.5^{\mathrm{d}}$ & $82.0 \pm 0.0^{\mathrm{a}}$ \\
F2 & $180.6 \pm 4.7^{\mathrm{a}}$ & $78.4 \pm 0.1^{\mathrm{b}}$ \\
F3 & $74.0 \pm 5.9^{\mathrm{b}}$ & $76.5 \pm 0.0^{\mathrm{b}}$ \\
F4 & $57.5 \pm 2.4^{\mathrm{c}}$ & $77.4 \pm 1.3^{\mathrm{b}}$ \\
\hline
\end{tabular}

Simple arithmetic averages $(\mathrm{n}=3) \pm$ standard deviation, followed by different lowercase letters in the same column, differ from each other by the Tukey test $(P<0.05)$. tone $\left(b^{*}=46.7\right)$ that may occur due to the carotenoid content present in the access. Nevertheless, in most cases, the contents of carotenoids vary markedly during industrial processing and storage conditions due to its significant number of double bonds in the structures (Rodriguez-Amaya, 2001).

Priori et al. (2012) analyzed the total carotenoid values of the pulps of nine accessions of Cucurbita maxima from Embrapa's active germplasm bank, finding values between 22.6 and $221.9 \mu \mathrm{g} . \mathrm{g}^{-1}$, in agreement with the values found in this study. Different accesses present distinct values of carotenoids; this difference can be attributed to genetic influence, climate, stage of maturity, and storage conditions. For a food product to be considered as a source of carotenoids, it is necessary to have at least $20 \mu \mathrm{g}$. $\mathrm{g}^{-1}$ or $2 \mathrm{mg} .100 \mathrm{~g}^{-1}$ (Rodriguez-Amaya et al., 2008), and therefore the pumpkin flours studied can be considered a source of carotenoids.

The four samples presented high digestibility values (76.5-82\%), and F1 presented higher protein digestibility $(P<0.05)$. Naves et al. (2010), evaluated pumpkin seeds (Cucurbita maxima), and reported values between 45.84 and $72.48 \%$, in raw and cooked pumpkins, lower values when compared to the present study. Digestibility is used to evaluate the use of a protein source, with the hydrolysis of proteins by digestive enzymes until smaller peptides and their absorption by the body, which would be biologically available, provided that there was no interference in absorption by the body (Ntatsi et al., 2018). When peptide bonds are not hydrolyzed in the digestive process, part of the protein is excreted in feces or metabolized by microorganisms in the large intestine (Mendes et al., 2007). Pumpkin seeds have antinutritional and toxicological factors, such as trypsin inhibitors, for example, hindering protein digestibility, and can be influenced by heat treatment, the presence of polyphenols, trypsin inhibitors, and lectins, among others (Cheftel, 1993).

\section{Conclusion}

This study provides high-value information on the characteristics of pumpkin flour for application in the food industry. It was verified that flours have high protein digestibility and intense yellow-orange color, so the intense color reflects on the potential to add these flours to improve the color of food products and increase consumer acceptance by the product. The low water activity exerted by flour also suggests excellent storage stability, as almost all reactions that contribute to food deterioration are delayed or wholly interrupted when food water activity is Reduced.

This pumpkin pulp-based flour can be applied in the food industry, such as thickener in soups and sauces by high water absorption, also as an ingredient for baking products such as bread, cakes, and instant noodles. Therefore, pumpkin flours have great potential to be used as functional ingredients or as flour composed with another cereal and pumpkin in the food processing industry.

\section{References}

Adams, G. G., Imran, S., Wang, S., Mohammad, A., Kok, S., Gray, D. A., Channell, G. A., Morris, G. A., \& Harding, S. E. (2011). The hypoglycaemic effect of pumpkins as anti-diabetic and functional 
medicines. Food Research International, 44(4), 862-867. http://dx.doi. org/10.1016/j.foodres.2011.03.016.

Alibas, I. (2007). Microwave, air and combined microwave-air-drying parameters of pumpkin slices. Lebensmittel-Wissenschaft + Technologie, 40(8), 1445-1451. http://dx.doi.org/10.1016/j.lwt.2006.09.002.

American Association Cereal Chemists - AACC. (1991). Approved methods (8th ed.). Saint Paul: AACC.

American Society of Agricultural Engineers - ASAE. (2000). Moisture measurement-unground grain and seeds. St. Joseph: ASAE.

Anderson, R. A., Conway, H. F., Pfeifer, V. F., \& Griffin, L. Jr. (1969). Gelatinization of corn grits by roll-and extrusion-cooking. Cereal Science Today, 14(1), 4-11.

Ascheri, J. L. R. (2009). Food extrusion process course: technological aspects for the development and production of food for human and animal consumption. Rio de Janeiro: EMBRAPA.

Association of Official Analytical Chemists - AOAC. (2005). Official methods of analysis (18th ed.). Washington: AOAC.

Augusto-Ruiz, W., Bonato, S., Arrieche, L., \& Risso, F. (2003). Characterization of pregelatinized brown rice flour produced from broken grains. Journal of Exact Sciences and Engineering, 13, 8-12.

Batista, J. E. R., Braga, L. P., Oliveira, R. C., Silva, E. P., \& Damiani, C. (2018). Partial replacement of wheat flour by pumpkin seed flour in the production of cupcakes filled with carob. Food Science and Technology, 38(2), 250-254. http://dx.doi.org/10.1590/1678-457x.36116.

Brasil, Agência Nacional de Vigilância Sanitária - ANVISA. (1998, January 16). Aprova o regulamento técnico referente à Informação Nutricional Complementar (declarações relacionadas ao conteúdo de nutrientes), constantes do anexo desta portaria (Portaria $\mathrm{n}^{\circ} 27$, de 13 de janeiro de 1998). Diário Oficial [da] República Federativa do Brasil.

Brasil. Agência Nacional de Vigilância Sanitária - ANVISA. (2003, December 26). Aprova regulamento técnico sobre rotulagem nutricional de alimentos embalados, tornando obrigatória a rotulagem nutricional(Resolução RDC n 360, de 23 de dezembro de 2003). Diário Oficial [da] República Federativa do Brasil.

Cheftel, J. C. (1993). Química de los alimentos (2nd ed.). Zaragoza: Acribia.

Fellows, P. J. (2006). Food processing technology: principles and practice (2. ed.). Porto Alegre: Artmed.

Ferreira, M. G., Salvador, F. V., Lima, M. N. R., Azevedo, A. M., Lima, I. S. No., Sobreira, F. M., \& Silva, D. J. H. (2016). Genetic parameters, dissimilarity and performance of pumpkin accessions. Brazilian Horticulture, 34(4), 537-546. http://dx.doi.org/10.1590/s0102053620160413.

Fraser, P. D., \& Bramley, P. M. (2004). The biosynthesis and nutritional uses of carotenoids. Progress in Lipid Research, 43(3), 228-265. http:// dx.doi.org/10.1016/j.plipres.2003.10.002. PMid:15003396.

Guiné, R. P. F., Pinho, S., \& Barroca, M. J. (2011). Study of the convective drying of pumpkin (Cucurbita maxima). Journal of Food and Bioproducts Processing, 89(4), 422-428. http://dx.doi.org/10.1016/j. fbp.2010.09.001.

Guz, E. A., Novitskaya, E. G., Kalenik, T. K., Levochkina, L. V., \& Piekoszewski, W. (2018). The influence of vegetable puree containing carotenoids on the nutrient composition and structure of milk yoghurt. International Journal of Dairy Technology, 71(1), 89-95. http://dx.doi.org/10.1111/1471-0307.12392.

Hoover, R., \& Ratnayake, W. S. (2001). Current protocols in food analytical chemistry. New York: John Wiley \& Sons.

Hsu, H. W., Vavak, D. L., Satterlee, L. D., \& Miller, G. A. (1977). Multienzyme technique for estimating protein digestibility. Journal of Food Science,
42(5), 1269-1273. http://dx.doi.org/10.1111/j.1365-2621.1977. tb14476.x.

Juliano, B. O. (1993). Rice in human nutrition. Rome: Food and Agriculture Organization of the United Nations.

Krist, K. A., Nichols, D. S., \& Ross, T. (1999). Ecology of bacteria and fungi in foods: influence of available water. In R. Robinson, C. A. Batt \& P. Patel (Eds.), Encyclopedia of food microbiology. London: Academic Press. http://dx.doi.org/10.1006/rwfm.1999.0450.

Lee, C. H., Cho, J. K., Lee, S. J., Koh, W., Park, W., \& Kim, C. H. (2002). Enhancing b-carotene content in Asian noodles by adding pumpkin powder. Cereal Chemistry, 79(4), 593-595. http://dx.doi.org/10.1094/ CCHEM.2002.79.4.593.

Maldonado-Robledo, G., Rodríguez-Bustamante, E., Sánchez-Contreras, A., Rodríguez-Sanoja, R., \& Sanchez, S. (2003). Production of tobacco aroma from lutein. Specific role of the microorganisms involved in the process. Applied Microbiology and Biotechnology, 62(5-6), 484488. http://dx.doi.org/10.1007/s00253-003-1315-6. PMid:12827317.

McGrance, S. J., Cornell, H. J., \& Rix, J. R. (1998). Simple and rapid colorimetric method for the determination of amylose in starch products. Stärke, 50(4), 158-163. http://dx.doi.org/10.1002/(SICI)1521379X(199804)50:4<158::AID-STAR158>3.0.CO;2-7.

Mehditabar, H., Razavi, S. M. A., \& Javidi, F. (2019). Influence of pumpkin puree and guar gum on the bioactive, rheological, thermal and sensory properties of ice cream. International Journal of Dairy Technology. In press. http://dx.doi.org/10.1111/1471-0307.12658.

Mendes, F. Q., Oliveira, M. G. A., Cardoso, L. R., Costa, N. M. B., \& Sant'ana, R. C. O. (2007). Protein digestibility and bromatological characterization of soybean genotypes with absence or presence of the trypsin inhibitor kunitz and lipoxygenases. Bioscience Journal, 23(1), 14-21.

Moreira, L. A. S., Carvalho, L. M. J., Cardoso, F. S. S. N., Ortiz, G. M. D., Finco, F. D. B. A., \& Carvalho, J. L. V. (2020). Different cooking styles enhance antioxidant properties and carotenoids of biofortified pumpkin (Curcubita moschata duch) genotypes. Food Science and Technology, 40(2), 302-306. http://dx.doi.org/10.1590/fst.39818.

Naves, L. P., Correa, A. D., Santos, C. D., \& Abreu, C. M. P. (2010). Antinutritional components and protein digestibility of pumpkin (Cucurbita maxima) seeds submitted to different processing. Food Science and Technology, 30(1), 180-184. http://dx.doi.org/10.1590/ S0101-20612010000500027.

Noor Aziah, A. A., \& Komathi, C. A. (2009). Physicochemical and functional properties of peeled and unpeeled pumpkin flour. Journal of Food Science, 74(7), S328-S333. http://dx.doi.org/10.1111/j.17503841.2009.01298.x. PMid:19895499.

Ntatsi, G., Gutiérrez-Cortines, M. E., Karapanos, I., Barros, A., Weiss, J., Balliu, A., Rosa, E. A. S., \& Savvas, D. (2018). The quality of leguminous vegetables as influenced by preharvest factors. Scientia Horticulturae, 232, 191-205.

Park, K. J., Bin, A., \& Brod, F. P. R. (2001). Sorption isotherms obtained and mathematical modeling for bartlett pear (Pyrus sp.) with and without osmotic dehydration. Food Science and Technology, 21(1), 73-77. http://dx.doi.org/10.1590/S0101-20612001000100016.

Pi-Sunyer, F. X. (2002). Glycemic index and disease. The American Journal of Clinical Nutrition, 76(1), 290S-298S. http://dx.doi.org/10.1093/ ajcn/76.1.290S. PMid:12081854.

Pongjanta, J., Naulbunrang, A., Kawngdang, S., Manon, T., Thepjaikat, T., \& Songklanakarin, J. (2006). Utilization of pumpkin powder in bakery products. Nutraceutical and Functional Food, 28(1), 71-79.

Priori, D., Barbieri, R. L., Vizzotto, M., Mistura, C. C., Carbonari, T., Barboza, L. F., Corrêa, A. P. A., Bialves, T. S., Vilela, J. C. B., \& Araújo, 
V. F. (2012). Carotenoides totais em acessos de Cucurbita maxima do banco ativo de germoplasma de cucurbitáceas da Embrapa Clima Temperado. In Anais do $2^{\circ}$ Congresso Brasileiro de Recursos Genéticos. Brasília: Sociedade Brasileira de Recursos Genéticos.

Que, F., Mao, L., Fang, X., \& Wu, T. (2008). Comparison of hot airdrying and freeze-drying on the physicochemical properties and antioxidant activities of pumpkin (Cucurbita moschata Duch.) flours. International Journal of Food Science \& Technology, 43(7), 1195-1201. http://dx.doi.org/10.1111/j.1365-2621.2007.01590.x.

Riaz, M. N. (2006). Soy applications in food. London: Taylor \& Francis.

Rodriguez-Amaya, D. B. (2001). A guide to carotenoid analysis in foods. Washington: ILSI Press.

Rodriguez-Amaya, D. B., Kimura, M., Godoy, H. T., \& Amayafarfan, J. (2008). Updated Brazilian database on food carotenoids: factors affecting carotenoid composition. Journal of Food Composition and Analysis, 21(6), 445-463. http://dx.doi.org/10.1016/j.jfca.2008.04.001.

Saeleaw, M., \& Schleining, G. (2011). Composition, physicochemical and morphological characterization of pumpkin flour. In Proceedings of the 11th International Congress on Engineering and Food "Food Process Engineering in a Changing World" (ICEF11). Athens: National Technical University.

See, E. F., Wan Nadiah, W. A., \& Noor Aziah, A. A. (2007). Physicochemical and sensory evaluation of breads supplemented with pumpkin flour. ASEAN Food Journal, 14(2), 123-130.
Silva, K. S., Caetano, L. C., Garcia, C. C., Romero, J. T., Santos, A. B., \& Mauro, M. A. (2011). Osmotic dehydration process for low temperature blanched pumpkin. Journal of Food Engineering, 105(1), 56-64. http://dx.doi.org/10.1016/j.jfoodeng.2011.01.025.

Tamer, C. E. (2010). Evolution of several quality criteria of low calorie pumpkin dessert. Notulae Botanicae Horti Agrobotanici Cluj-Napoca, 38(1), 76-80.

Tavares, J.-A. S., Soares, M. S. Jr., Becker, F. S., \& Costa, E. E. (2012). Functional changes of microwave roasted rice flour as a function of moisture content and processing time. Rural Science, 42(6), 1102-1109. http://dx.doi.org/10.1590/S0103-84782012000600025.

Wang, P., Liu, J. C., \& Zhao, Q. Y. (2002). Studies on nutrient composition and utilization of pumpkin fruit. Journal of Inner Mongolia Agricultural University, 23(3), 52-54.

Yildiz, E., \& Ozcan, T. (2019). Functional and textural properties of vegetable-fibre enriched yoghurt. International Journal of Dairy Technology, 72(2), 199-207. http://dx.doi.org/10.1111/1471-0307.12566.

Yok, M. C. K., Gisong, S. A. D., Modon, B. A., \& Rusim, R. (2016). Creating new market in integrated agriculture development area in Samarahan, Sarawak, Malaysia: case study in the supply chain of Cucurbita sp. (Pumpkin). Procedia: Social and Behavioral Sciences, 224, 516-522. http://dx.doi.org/10.1016/j.sbspro.2016.05.428.

Zhang, F., Jiang, Z. M., \& Zhang, E. M. (2000). Pumpkin function properties and application in food industry. Science and Technology of Food Industry, 21, 62-64. 